\title{
ULTRASTRUCTURE OF PIGMENTED PHOTORECEPTOR OF ADULT CREPIDOSTOMUM METOECUS (TREMATODA: DIGENEA: BUNODERIDAE)
}

\author{
Zdeňka Žd’árská and Jana Nebesářová
}

Institute of Parasitology, Academy of Sciences of the Czech Republic, Branišovská 31, 37005 České Budějovice, Czech Republic

In adult fish trematode Crepidostomum metoecus (Braun, 1900) two pigmented eyespots were detected dorso-laterally to the pharynx. In contrast to most other digenetic trematodes the eyespots in C. metoecus persist throughout the life (cercaria, metacercaria, adult), but their role in the biology of the adult trematode is uncertain.

The ultrastructure of the eyespots in Digenea has been studied in miracidia and cercariae only (e.g., Pond G.G., Cable R.M. 1966: J. Parasitol. 52: 483-493; Isseroff H., Cable R.M. 1968: Z. Zellforsch. Mikrosk. Anat. 86: 511-534; Rees F.G. 1975: Proc. R. Soc. Lond. B 188: 121-138; Fournier A. 1984: Photoreceptors and photosensitivity in Platyhelminthes. In: M.A. Ali (Ed.), Photoreception and Vision in Invertebrates, Plenum Publishing, New York, pp. 217-239; Van de Roemer A., Haas W. 1984: Z. Parasitenkd. 70: 391-394). No ultrastructural data on eyespots in adult digenetic trematodes are available.

Our TEM studies of serial sections of both eyespots of adult $C$. metoecus revealed a single retinular cell associated with a pigment cell. The eyespots of the adult trematode are rhabdomeric. A dendritic process of the retinular cell enters the chamber of the pigment cell and branches into microvilli, the so-called rhabdomere. The rhabdomere consists of a narrow core of cytoplasm bearing densely-packed parallel microvilli (Figs. 1-4). The boundary between the region of the retinular cell bearing microvilli, and the chamber of the pigment cell, is marked by an annular electron-dense septate junction (Figs. 2, 3). This septate junction (termed the annulus by some authors) connects tightly the retinular and pigment cells. The portion of the retinular cell localised outside the pigment cell chamber (Fig. 1) contains electron-dense neurovesicles, Golgi complexes, mitochondria, rough endoplasmic reticulum and the nucleus.

The pigment cell consists of two parts, one part with the chamber enclosing the rhabdomere of the retinular cell (Figs. 1-4), and another part opposite to this chamber forming long extensions (Figs. 4-6) which penetrate the intercellular spaces, thus giving the pigment cell a stellate shape. A dense nucleus is localised between these two parts (Fig. 5). The part of the pigment cell forming the chamber contains, next to the cavity, a layer of condensed electron-dense pigment granules and electron-lucid vacuoles (Figs. 1-4). The contents of the electron-lucid vacuoles are amorphous, but occasionally membrane-bound whorls occur inside. These vacuoles may represent lipid droplets extracted during tissue preparation. The opposite part of the pigment cell, forming long extensions, contains isolated electron-dense pigment granules with a vacuolated central part, and mitochondria (Figs. 5, 6).

Usually, photoreceptors of the cercaria disintegrate as it develops into the adult, and their pigment is scattered through the parenchyma of the forebody, but the degree to which that process occurs varies. Our TEM study of serial sections confirmed that in the eyespot of the adult digenetic trematode C. metoecus a single retinular and a single pigment cell are preserved. In many details the structural organisation of the eyespot of the adult trematode is similar to the eyespot of the cercaria Crepidostomum sp. described by Pond and Cable (1966, op. cit.). The main difference between the eyespot of the adult trematode, studied by us, and the above-mentioned cercaria, is the shape of the pigment cell. This cell in the cercaria is round or oval, but in the adult trematode the pigment cell forms long narrow extensions located in the intercellular spaces, giving the cell a stellate shape. In aged adults the pigment granules of the pigment cell extensions are probably released into the intercellular spaces of the forebody. Some eyespots or dispersed pigment granules in the forebody of adults of the family Bunoderidae are mentioned in taxonomic papers on trematodes (e.g., Skryabin K.I., Koval V.P. 1966: Family Bunoderidae Nicoll, 1914. In: K.I. Skryabin (Ed.), Trematodes of Animals and Men. Essentials of Trematodology XXII. Nauka, Moscow, pp. 311-456).

This study was supported by the grant No. 524/00/0267 from the Grant Agency of the Czech Republic. 

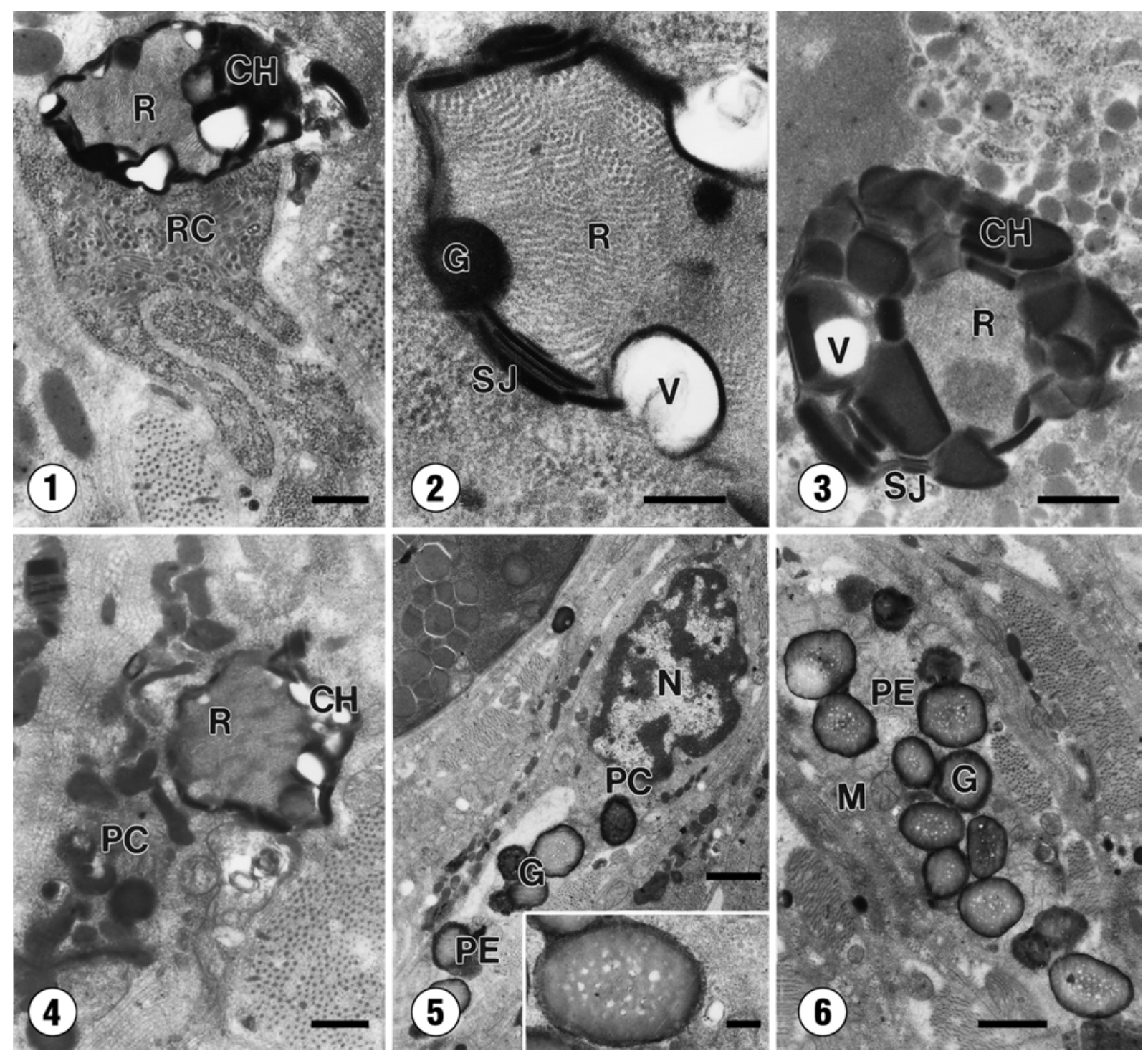

Figs. 1-6. Photoreceptor of Crepidostomum metoecus, transmission electron micrographs. Fig. 1. Rhabdomere (R) of the retinular cell $(\mathrm{RC})$ enclosed in the chamber $(\mathrm{CH})$ of the pigment cell. Fig. 2. Detail of rhabdomere microvillous part (R), septate junction (SJ), pigment granulum (G) and electron-lucid vacuoles (V). Fig. 3. Pigment cell chamber (CH) formed by a layer of condensed pigment granules and connected to the rhabdomere cytoplasmic part (R) by a septate junction (SJ); V - electron-lucid vacuole. Fig. 4. Part of the pigment cell $(\mathrm{PC})$ in the vicinity of the pigment cell chamber $(\mathrm{CH})$ and rhabdomere $(\mathrm{R})$. Fig. 5. Part of the pigment cell (PC) opposite to the pigment chamber; $\mathrm{N}$ - nucleus, $\mathrm{PE}$ - pigment cell extension, $\mathrm{G}$ - pigment granules. Inset: detail of pigment granulum. Fig. 6. Pigment cell extension (PE) containing pigment granules $(\mathrm{G})$ and mitochondria (M). Scale bars: Figs. 1, 3, 4, = $400 \mathrm{~nm}$; Figs. 2, 5 (inset) $=200 \mathrm{~nm}$; Figs. 5, $6=1 \mu \mathrm{m}$. 